\title{
(Dis)locating Control:
}

Transmigration, Precarity and the Governmentality of Control

\section{joshua j. kurz}

\section{Abstract:}

In this essay, the author takes up William Walters' (2006) incitement to theorize transmigration through the Deleuzian concept of control. The importance of mechanisms, or technologies, that modulate population flows are explored by paying close attention to novel strategies of migration policing and securitization in the United States, the European Union, Australia, and North Africa. These technologies no longer take the border as their "proper" site, but instead rely on processes of internalization, externalization, and excision to produce conditions of generalized precariousness. The author argues that these technologies of control resist simple categorization as biopolitics, and instead are more fruitfully considered through the lens of control societies and precarity. Ultimately, the inclusion/exclusion dialectic is put under erasure.

joshua j. kurz is a PhD Candidate in the Department of Comparative Studies at Ohio State University. He is currently researching and writing his dissertation, entitled "The Figure of the Refugee: Displacement, Mobility and the Coming Politics." His broad areas of research interest are political theory and philosophy, refugee and migrant securitization, and autonomous politics.

E-Mail: kurz.32@osu.edu
Keywords: precarity, control, biopolitics, Deleuze, topological borders

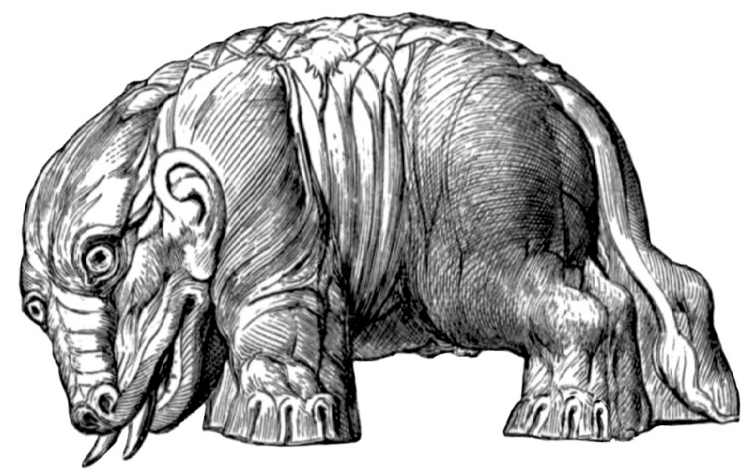




\section{Introduction}

In this essay[1] I take up William Walters' (2006) incitement to theorize transmigration in light of Gilles Deleuze's concept of control societies (1995). I analyze specific technologies by which states control population flows, which places transmigration in a context that takes the will to govern human movement in a relationship with both the mechanisms and institutions that enable that governance - the result being a generalized condition of precarity. Generally, the technologies elaborated below move away from a logic of border enforcement - a logic of inclusion and exclusion - to a logic of population modulation - or the foregrounding of the mechanisms by and through which we modulate relationships, flows, and knowledge.[2] Operating through processes of externalization, internalization, and excision, the governmentality of control has become highly selective, uneven, and discontinuous even while retaining a will to universal application.

Michael Collyer (2007) points to the "fragmented journey," or the fact that migration can no longer be thought of as a journey with a discrete beginning and end, but instead as a protracted life experience. Interpretations abound, but to name two: Glick Schiller et al. note that today's immigrants "develop networks, activities, patterns of living, and ideologies that span their home and the host society" (Glick Schiller/Basch/Blanc-Szanton 1994, 7) resulting in a form of "transnational” subjectivity; Bauman's $(1998 ; 2004)$ interpretation of the phenomenon stresses both the excess "wasted lives" produced by globalization, as well as the "travelers" and "vagabonds" who differentially experience mobility. From new subjectivities to the "waste" products of modernity, the point is the same: life is no longer territorially and temporally linear, it is mobile, nomadic. Given this ontology of movement, human mobility is often perceived as a danger to states yet essential for the functioning of capital; the question, has become one of modulation: how do states encourage 'acceptable' flows while discouraging 'unacceptable' ones? In other words, the target is not primarily the subject, but is instead the regulation of a flow of mobile bodies. Therefore, transmigration as a logic of government is not concerned with the physical presence of migrants in a country, but is rather preoccupied with capturing migration flows and modulating them on a global scale in an attempt to produce specific effects. States and state actions, however, are only one aspect of control societies. Attention must be paid to other transnational forms of governance not considered here for reasons of space: Frontex, the International Organization for Migration, the United Nations, and so on. Various institutions
[1] I would like to thank Philip Armstrong, Mathew Coleman, Austin Kocher, Andrew C. Culp, Oded Nir, Eugene Holland, and an anonymous reviewer for comments on, contributions or improvements to various portions of this paper. Ultimately, of course, any shortcomings are mine alone. [2] To clarify, when I refer to "population modulation," I mean it as shorthand for "modulation of population flows," or "modulation of a population's membership." I recognize, however, that one cannot "modulate" a whole population, as will become clear. Modulation is like: using the tuner on a radio to hone in on a frequency; using a muting device on a trumpet to change the volume and frequency of the sound; redirecting flows of water. What is common are the attempts to set limits on processes or phenomena that a) exceed the limits as an expected matter of course, and b) are interventions more than they are "shapings" or "craftings". Population modulation is not, then, about the inclusion/exclusion decision - we would merely be re-treading sovereign power - but about the diffusion of mechanisms in a global political space that filters, directs, and augments, but does not decide. 
and organizations may have "management goals," but taken together, the system is decentered. Precarity, therefore, enters as a result of a process without subjects, the opposite of a management paradigm.

This essay begins by addressing recent ethnographic and theoretical work on various technologies of transmigrant policing and securitization. These technologies indicate a shifting logic of governance away from the sole provenance of the internal/external logic of border enforcement and toward the blurring of the external and internal within a logic of population modulation. I assert that these assemblages of technologies of population modulation are not, as Foucault argued of biopolitics, concerned with making life more productive, but instead tend to produce generalized conditions of precarity. Following Deleuze's "Postscript on Control Societies," I argue that while there are biopolitical moments and techniques at work in the present, it is more accurate and productive to explore how a mode of power has once again "intensified" (Nealon 2008) into a new paradigmatic form. I propose, then, that what we are seeing is not a "population management" paradigm (i.e biopolitics), but one of "population modulation" (i.e. control).[3] This article gestures towards a theory of transmigration and precarity as a new (or if not new, at least novel) politics of human migration.

\section{Modulation Away from the Border: Technologies of Migration Poli- cing and Securitization}

There has been an increase in research documenting technologies of migration control that no longer take either the border as their 'proper' site or territorial exclusion as their primary goal.[4] This can be, and has been, conceptualized as a shift from a logic of border enforcement (discourses of sovereign power) to, broadly speaking, a logic of population management (discourses of biopower). Yet I take Foucault's work on biopolitics to be delimited by its historicity and specificity: essentially, biopolitics is not merely taking life to be the central concern of politics;[5] it is the establishment of a regime of security over a territory for the purpose of making the population more productive. [6] What we see today is different in both operation and effect, in that contemporary governance is no longer territorial (although it retains territorial elements),[7] nor is it directed at a bounded population (although it does not supersede population-level projects entirely), nor is it about the
[3] I realize that modulation can be interpreted as another form of management. I assert, however, that it is not. Management is teleological, outcome-oriented; it is about accomplishing goals set along a predetermined path toward a predetermined end. Modulation, however, is about speed, the amplification or sublimation of turbulence, rhythm; it is about amplifying and redirecting flows whose cause exists outside of the purview of modulation. In short, modulation has no goals, no plan. As I will show, population modulation is not about exclusion or discipline, but about the selective function of moving people into or out of close proximity to control mechanisms. Management and modulation are qualitatively different.

[4] A selection of this research: Bakker 2010; Bigo 2001, 2007; Bigo/Guild 2005; Bonelli 2005; Coleman 2007; Coleman/Kocher 2011; Crowley 2005; Geiger 2010; Groenendijk 2003; Guild 2003; Inder 2010; Kasparek 2010; Marchetti 2010; Mountz 2010; Poutignant/Streiff-Fénart 2010; Zolberg 2003.

[5] As could be concluded from a reading of The History of Sexuality, volume 1 (Foucault 1990).

[6] I will go into this in more detail later in this essay, but a clarification is in order for now. Much of what is discussed under the rubric of biopolitics falls into one of several distinctions generally associated with a particular theorist:

1) Agamben's understanding of biopolitics, sovereignty, and bare life,

2) Esposito's understanding of biopolitics as immunity, 3) Hardt and Negri's distinction between biopolitical production and biopower,

4) and finally, what Schinkel (2010) highlights, the distinction between a biopolitics and zoepolitics (where I would place someone like Rose 2007).

I take Foucault's definition of biopolitics because a) it takes into account both individuals and masses, b) it is oriented 
preservation and promotion of life (although it sometimes does this). To be more precise, there is a new diagram of power at work that is primarily indifferent towards life... except only when it is strategically useful to be otherwise. This helps to explain why both Foucault's lectures in The Birth of Biopolitics (2008) and Deleuze's essay on control (1995) largely ignore the term "biopolitics" and instead, respectively, focus on neoliberalism and the transition from discipline to control. In effect, both recognize that biopower is a constitutive component of a different set of technologies with different ends. Indeed, Protevi notes that after 1980, biopolitics and control are contemporaneous, and work through distinct modes, actors, targets, practices, forms, outcomes, and so on.[8] Following Nealon's (2008) notion of the intensifications of power, Protevi points out that biopolitics and control are in fact complementary, but that in a control society what matters more than life itself are the mechanisms by which life is put in relation to and modulated with the political, the economic, and the social.[9]

This portion of the essay will extend the genealogy of control societies begun by Deleuze by focusing on technologies of control as they concern transmigration. I first discuss trends of internalization in the United States, followed by trends of externalization in the European Union, and I conclude with a discussion of the excision of territory in Australia. This is not because such trends are limited to those contexts; I am merely providing a heuristic based on the primary (perhaps hegemonic) trends in each area. To be clear from the outset, this essay is an exploration of the global trends in transmigrant control technologies, and therefore will necessarily obscure some significant local technologies and practices. For example, there is a significant tension in the EU between union-led initiatives and autonomous member-state practices. Over the past two decades, there has been an ebb and flow of efforts to harmonize immigration policies (Luedtke 2009; Mitsilegas 2009) and asylum policies (Thielemann 2009); however, viewed over the period from World War II to the present, it is clear that EU member-states have engaged in a long process of externalization, first from the "core" (Germany and France) and then to the "periphery" (Finland, Poland, etc.). Another example: the US has engaged in significant externalization practices, not least of which involved the pressuring of Mexico to control migration on its southern border as part of North American Free Trade Agreement (NAFTA). I am in no way arguing that the trends I discuss below - internalization in the US, externalization in the EU, and excision in Australia - are limited to those locales. On the contrary, I am trying to highlight the geographic proliferation of practices that fundamentally alter towards production, c) it is clearly territorial, and d) it is historicized as a governmentality. Crucially, then, it is not simply taking any life as the object and end of a politics, but a specific form of life, in a particular time and place, for specific ends (Foucault 2003; 2007; 2008).

[7] Traditionally, territory is rather simply defined as a bordered or bounded space. This essay is an attempt to elaborate upon insights that are fundamentally rethinking territory/ territoriality (see Popescu 2012; Elden 2011).

[8] Protevi graciously posts this chart - and many other resources - to his website, http://www.protevi.com/john/ Foucault/index.html.

[9] For example, rather than the biopolitics of the welfare state, control is a debt society, where the selective mechanisms of the credit scores and reports determined by private corporations combine with welfare state loan institutions like Freddie Mac. The relation is far more important than the outcome of the loan process. 
the site of transmigrant policing, with a view to a novel governmentality of control. To foreshadow elements of the essay, I am reading these technologies of control against biopolitical technologies, because the control mechanisms I discuss below abandon the securitization of life and territory, in favor of an open systems, which blur the interior/exterior dialectic into zones of indistinction, and that require modulation rather than "management."

Didier Bigo (2002) offers an entry point into the study of technologies of control in his essay,

"Security and Immigration: Toward a Critique of the Governmentality of Unease." He argues that The securitization of migration is...a transversal political technology, used as a mode of governmentality by diverse institutions to play with...unease, or to encourage it if it does not yet exist, so as to affirm their role as providers of protection and security and to mask some of their failures. (Bigo 2002, 65)

In this view, human migration is a source of anxiety that is intentionally played upon by governments, security professionals, and other individuals and institutions as a technology to justify their own existence and operational modalities. He calls this the "governmentality of unease." Bigo presents a convincing case for how unease, or what I call here precarity, is being captured and enhanced by non-governmental and governmental forces alike. By amplifying social anxiety, traditionally stable portions of the populace are made to feel precarious, as if global migration flows are a threat to their very existence. Securitization regimes are instituted in response that must have the appearance of responding to the 'threat,' but must also be flexible enough to be open to massive migratory flows that are a fundamental necessity to contemporary capitalism. To achieve both, the specific technologies that modulate population flows are designed to keep migrants precarious, in ways that stratify the population and incapacitate them politically (Coleman/Kocher 2011).

In the US, this incapacitation is produced in myriad ways, but perhaps the most visible contributor is the intensified emphasis on deportation. Typically associated with a logic of inclusion/ exclusion, deportation today instead operates in an open system, networked with various other technologies to move beyond mere population management. Deportation is no longer about reinforcing the space of enclosure (i.e. US border sanctity), but instead "thins" the population selectively. In short, deportation is responding to a larger tendency in migration policing, where the territory is no longer coterminous with rights, membership, and social reproduction:[10] Coleman and Kocher, for
[10] Hardt and Negri (2000; 2004; 2009) identify a tendency in contemporary capitalism, away from industrial labor and towards what they call immaterial labor. As they note, this does not mean that industrial production does not occur, or that immaterial labor is evenly present around the globe. Rather than strictly replacing industrial labor, the tendency toward immaterial labor is like an attractor, or gravitational center, around which industrial labor realigns and through which it becomes shaped. This is parallel to what I see happening with the shift to the paradigm of population management. 
example, illuminate "a geopolitics of civic stratification" that results in "immigrant incapacitation," as "detention and deportation practice as a 'management of populations'...is not tethered explicitly to the 'management of territory' in terms of physically removing non-citizen individuals" (234).

With the rise of the use of local police officers as proxies for federal immigration enforcement officials, the number of deportations has risen drastically since 2006, yet it is evident that the primary mode of policing these individuals does not occur at the border. Coleman (2007; see also Bigo 2001) points to the blurred lines between external and internal security in the paradigm of population management. This blurred line dislocates policing and deterritorializes it from traditional sites of enforcement such as the border or the workplace. Working concurrently with the routinization of detention and deportation, the dejuridicalization of immigration enforcement, the expansion of the criminal infractions that now serve as grounds for deportation, and the sharp rise in the involvement of non-federal officers in immigration policing, it has become clear that the primary site of immigration policing now occurs well away from the border. The primary site of enforcement is no longer the border, but neither is it the workplace, regardless of recent high-profile workplace raids in the US. It is the sites of social reproduction, leisure, and transportation, fully internalized within the 100-mile border zone, in which population modulation occurs. As Coleman (2007) notes, the "new spaces of immigration geopolitics suggest that the border - and border enforcement - is increasingly everywhere" (64).

However, "everywhere" is not as general as the term seems. Primarily, immigrant policing in the US is happening in sites that are localizable and selective. For example, a primary tool of law enforcement is the traffic stop, especially in the form of license checkpoints. These checkpoints are mobilized ostensibly to screen every vehicle and driver passing through the checkpoint for a valid license; routinely, however, this is used as an excuse in order to facilitate the policing of immigration status. Since these stops are often limited to roads that lead from large workplaces to domestic areas with high immigrant populations, they qualify as a selective technology that has the effect of disciplining large numbers of immigrants without actually physically encountering each of them. This discipline results in incapacitation (Coleman/Kocher 2011) but is no longer part of the closed system of enclosures, an integral part of how Foucault characterized biopolitics in Society Must Be Defended and Security, Territory, Population. Instead, traffic stops are relatively open systems, part of a network of policing techniques designed to incapacitate and make precarious. 
When the traffic stop is combined with the growth in the number of local law enforcement officers charged with immigration policing responsibilities, the result is non-immigration related offenses leading to immediate or delayed, but almost inevitable, contact with federal databases, which result in an increase in deportations. Federal programs, such as the $287(\mathrm{~g})$ program,[11] effectively deputizes local law enforcement officials, allowing them to access federal databases otherwise closed to them, and at other times obligating police to detain immigrants indefinitely until status can be verified. Coleman and Kocher (2011) argue that this assemblage of technologies results in a form of discipline that results in the "production of a docile population of 'territorially present' residents" who are not "legally present." In other words, they can be deported but they cannot, for example, take an employer to court to claim lost wages. They further propose that "in the abstract immigration enforcement works through the production of an exemplary migrant precarity, i.e. an amplification of socio-economic and legal insecurities for certain immigrant bodies" (235). This uneven and selective enforcement helps explain why, for example, there is such a contradictory presence of "illegal" immigrants even after a meteoric rise in spending on, ostensibly, keeping them out.

I now turn to the EU and externalization. Collyer (2007; 2010) notes how the EU delegates immigration control to other countries in a series of articles on "stranded migrants and the fragmented journey." The EU attempts to establish a sort of "remote control" through visa controls, carrier sanctions (i.e. airline penalties), and airport liaison officers (see also Zolberg 2003). Collyer's primary finding is that due to the externalization of EU immigration enforcement, many of the migrants heading to Europe end up, for all intents and purposes, permanently residing just outside the border of the EU in places like Morocco or Tunisia. These migrants engage in a sort of ad hoc migratory pattern that is largely dependent upon hearing about opportunities for employment in one place, the leniency of an asylum granting officer in another, or the opportunities of clandestine migration into an EU member state from yet another place, thereby fragmenting the journey and deemphasizing the beginning and end points for the life experience of the journey itself.

An integral aspect of "remote control" is the prevalence of bilateral agreements between EU member states and its immediate neighbors, especially those in North Africa (Adepoju/van Noorloos/Zoomers 2009).[12] These agreements can be formalized, but EU member states tend to prefer informal agreements for a number of reasons. Informal agreements are less transparent, more flexible in the interpretation of human rights claims, especially the obligation of nonrefoulement,
[11] "The 287(g) program...allows state and local police to investigate immigration cases and ultimately make immigration arrests on behalf of federal authorities. There are two basic types of $287(\mathrm{~g})$ authority: the jail enforcement model and the task force model" (Coleman/Kocher 2011, 231). The jail model has authorities check immigration status as persons are booked into jail; the task force model allows nonfederal officers a broad discretion to investigate and arrest immigration-related offenses as part of routine policing.

[12] Bilateral agreements are slowly giving way to Frontex/ EU led agreements. This shift deserves recognition, but does not detract from the historical argument being made here. It remains to be seen how Frontex will alter the externalization of policing, but my suspicion is that it will extend the process rather than curtail it (see Kasparek 2010). 
and subject to quick alteration based on a perceived crisis. Hamood (2008) points to the proposal to create "transit processing centers" in countries bordering the EU (20). Such centers would serve as administrative and detention sites to prevent migrants and asylum seekers from reaching EU territory, where human rights obligations would set in. These bilateral agreements extend well beyond the establishment of camps, however, and include development aid, preferential immigration quotas, and circular migration schemes (Adepoju et al. 2009).

These bilateral agreements reached their zenith in a series of arrangements between Italy and Gaddafi's Libya.[13] The agreements generally stressed the use of Libya's military to intercept clandestine immigrants in the Mediterranean (Hamood 2008; Adepoju et al. 2009; Andrijasevic 2009). A 2003 agreement placed Italian police officers in Tripoli full-time to provide Libya with "training and equipment, in particular to assist border surveillance and management” (Hamood 2008, 32). A 2008 deal between the countries includes a provision that allows Italy to return intercepted migrants to Libya. As previously noted, these technologies of remote control result, in part, in a protracted or fragmented journey (Collyer 2007; 2010) and effectively deny political, religious, and ideological refugees the human rights protections many of the EU member states themselves were instrumental in securing. In short, then, in the same way that the US produces incapacitation and precarity in its interior, the EU's externalization of policing has the same effect.

A final problem posed to understanding the contemporary governance of transmigration is the strategic manipulation of territory, or excision, that deeply troubles the "security, territory, population" triplet posed by Foucault (2007). The US, EU, and Australia all engage in the strategic manipulation of territory to create exclusion zones that are formally part of the national territory, but legally outside of the spaces in which migrants can claim workers' rights or refugees can potentially claim asylum (Mountz 2010). For example, Australia has responded to an influx of asylum seekers by exercising the "power of excision," or the declaration of "hundreds of islands off the coast of Australia [as] no longer part of Australian territory for the purposes of migration" (xviii). Especially in the case of Australia - but also relevant to Italy and the island of Lampedusa - Mountz notes that,

[b]orders are thus pushed farther away and nearly erased... [and] asylum processing is contracted out to poorer countries. This combines with remote detention (inside sovereign territory) to create a powerful geography of exclusion. (127)
[13] After the collapse of Gaddafi's regime in Libya it is difficult to know for sure whether such an agreement will be reestablished - as of the time of writing this was not clear although it would be a safe assumption to imagine that Italy and the EU will base almost any aid to a fledgling Libyan government on the reduction of migrants and asylum seekers setting forth from the Maghreb. 
These geographies of exclusion are an intriguing aspect of the paradigm of population modulation, in that they effectively curtail the sovereignty states are ostensibly protecting from "extreme" population flows.

There is a danger of overstating the prevalence of these new technologies of population modulation and reducing the border to a merely (and weakly) performative status. It is true that borders are performative (Brown 2010; Coleman/Kocher 2011), as iterations of both the extent of sovereign power and the 'container' of rights claims. However, any study of borders/bordering and adjacent policing practices will show just how powerful these spaces remain. But as a tendency, borders are now responding to the paradigm of population modulation, or what Deleuze termed "control" (Deleuze 1995). It is not an overstatement, then, to note that the combination of internalization, externalization, and excision is drastically changing the way migration is governed. Indeed, "security" is becoming highly selective, wherein control is specifically located and precarity is produced throughout the global population. What the preceding section illustrated is the erosion of the inclusion/exclusion dialectic we have for so long associated with nation-state sovereignty. This dialectic is put under erasure, a process in which the traces of the border management paradigm persist, but we indeed have a new paradigm at work, and governing transmigration is an integral component of its operation. This new paradigm, a governmentality of control, abandons the life and security of populations in favor of control mechanisms aimed at transmigrant bodies in indistinct spaces that blur the interior and the exterior.

\section{Biopolitics and Control Societies}

There is a significant literature addressing biopolitics, and it continues to grow.[14] This is an extremely valuable development, and my goal is not to try and diminish this branch of political theorizing. However, I think that there are limits to the discourses of biopolitics, in particular with the way we can conceptualize the technologies of population modulation detailed thus far. Here I will build a case for why I think Foucault's initial elaboration of the concept is the one closest to a meaningful biopolitics, and why contemporary technologies of transmigration policing and securitization require a different framework, one provided by Deleuze in his brief reflections on control societies. In short, the concept of control provides us with more specific targets to attack if the goal
[14] Just to point to a sampling of the recent books on biopower: Agamben 1997; Campbell 2011; Clough/Willse 2011; Esposito 2008; Lemke 2011; Rose 2007; and others. 
is to weaponize precarity and use it against the coercive actions of states, rather than sublimate it back into the liberal project of 'human rights management.' Whereas Hardt and Negri are perhaps too enthusiastic about the decline of state sovereignty, and Agamben is perhaps too pessimistic, Deleuze provides a wedge by focusing on technologies of modulation rather than on life,[15] biopolitical production, or the sovereign.

\section{Foucault and Biopower}

Among Foucault's many innovations was to map the shifting terrain of power and the techniques and mechanisms through which it operates at specific historical junctures. His first major contribution to the theorization of power was to discuss the shift from a paradigm of sovereign power to one of disciplinary power. This shift is followed closely by the development of biopolitics. As Jeffrey Nealon (2008) explains, these new forms of power do not supersede the old ones, in that, for example, disciplinary power does not replace sovereign power. Instead, these new forms of power are intensifications, because they come up alongside the old power regimes and produce new power assemblages that further and further saturate human life into the grids of intelligibility of state and capital. The intensifications however, are not parallel, they are paradigmatic. For example, when disciplinary power becomes hegemonic, sovereign power does not disappear but becomes bent to the orbit of discipline; when biopower becomes hegemonic, sovereign power and discipline come to orbit around biopower. It is intensification and reorientation around a new paradigm; or, the creation of a new "gravitational center" around which everything else revolves.

Sovereign power is a representative model of power, in that all power relationships refer back to the monarch and that power is performed in and through representations. In Discipline and Punish, Foucault discusses the king's court as a display of the monarch's power. The techniques of punishment under sovereign power also operate in a representative register. For example, to enter the disciplinary gaze of the king, one had to symbolically violate the king's body, i.e. by committing patricide, the symbolic murder of the king. This is why torture and execution were performative. They were meant to display the power of the king after an offense that violated the king's sanctity. The power over life was "one of sovereignty's basic attributes" (Foucault 2007, 240). Foucault explains:
[15] Of course, Deleuze only talks about life, but in a drastically different register. 
In one sense, to say that the sovereign has a right of life and death means that he can, basically, either have people put to death or let them live, or in any case that life and death are not natural or immediate phenomena which are primal or radical, and which fall outside the field of power.

Life then entered into political considerations only in that the sovereign could, at will, take it away. This is significant, in part, because it was an absolute right over life and death, albeit one "conditioned by the defense of the sovereign, and his own survival" (1990, 135). In addition, while an absolute power, it was not totalizing; the gaze of the sovereign was discontinuous, relatively easy to escape:

This is a technology which aims to establish a sort of homeostasis...One might say this: It is as though power, which used to have sovereignty as its modality or organizing schema, found itself unable to govern the economic and political body of a society that was undergoing both a demographic explosion and industrialization. So much so that far too many things were escaping the old mechanism of the power of sovereignty, both at the top and at the bottom, both at the level of detail and at the mass level. (Foucault 2003, 249)

A new form of power developed in order to close the gap between the sovereign and individual bodies, and between the level of detail and at the mass level.

Disciplinary power alters the sovereign power regime and works in conjunction with it, intensifies it (indeed, sovereignty does not disappear, but instead becomes the preoccupation of the following decades/centuries). Sovereign power was spectacular, produced in moments of relative rarity on specific bodies. Disciplinary power changes this relationship from the spectacular exertion of power on a specific body to the everyday operation of power through a series of enclosures on all bodies. Rather than the singular gaze of the king, disciplinary power relies on the proliferation of enclosure institutions (the hospital, prison, school, and the nation-state) that overlap and complement one another in order to produce subjects at the level of the body. The gaze is intensified and diffused at the same time. Discipline takes as its central problematic the production of ideal subjects - i.e. the Citizen. 
Biopower, in Foucault's terms, is the shift in the logic from a concern with individual bodies to a concern with the population as a population, as a mass body:

Now I think we are seeing something new emerging in the second half of the eighteenth century: a new technology of power, but this time it is not disciplinary. This technology of power does not exclude the former, does not exclude disciplinary technology; but it does dovetail into it, integrate it, modify it to some extent, and above all, use it by sort of infiltrating it, embedding itself in existing disciplinary techniques. This new technique does not simply do away with the disciplinary technique, because it exists at a different level, on a different scale, and because it has a different bearing area, and makes use of very different instruments...after a first seizure of power over the body in an individualizing mode, we have a second seizure of power that is not individualizing but, if you like, massifying, that is directed not as man-as-body but at man-as-species. After the anatamo-politics of the human body established in the course of the eighteenth century, we have, at the end of that century, the emergence of something that is no longer an anatamo-politics of the human body, but what I would call a 'biopolitics' of the human race. (Foucault 2003, 242f., emphasis mine)

The logic of this new technique of power is not "to let live and make die," as in sovereign power, but "to make live and let die." So, by paying attention to the subject of power, we can trace its intensifications from the exceptional body (sovereign power) to the individuated body (discipline) to the massified body, or the entire population (biopower); with each intensification power mobilizes older forms in new ways, largely in operating on a new object or with new effects. Biopower, in making live, is an incitement to (re)produce freely and abundantly, to extend the lifespan, to control disease, to measure the effects of mechanisms meant to secure this population's productivity. In other words, to produce a surplus population. It is not a coincidence that discipline (as Deleuze notes, the "preeminent instance of the enclosed environment") and biopower (an effect of urbanization and public health) arise in conjunction. But what happens after the population is secure and productive, healthy and disciplined? The subject has changed, sovereign and disciplinary powers do not need to function the same way - indeed, they become excessive and are rebelled against (for example, the 1960s antiprisons and anti-psychiatry movements, free love against the family, and flexible labor against the welfare state). What is clear in Foucault's work, then, is that both discipline and biopower rely on 
enclosures, and the segmentation of human life into various disciplines, professions, institutions.

The contemporary crisis of enclosure institutions is partly a crisis in their territoriality. Various forms of power take different territorialities:

Sovereign power: the king's court, the pillory, the imperium bello where territorial expansion was displayed in the king's medals rather than through the setting of 'secure' borders.

Discipline: enclosures - i.e. hospitals, prisons, factories, the family unit; institutions with overlapping territorialities working on the body - i.e. the co-presence of church and state exacting allegiance and discipline.

Biopower: nations as enclosures; nationalism and state racism; presumes and intensifies disciplinary enclosures; utilizes the givenness of an already existing set of forces to increase productivity/health/lifespan.

Biopower, then, works primarily through closed systems, or at best through partially open ones. However, as Ong (2006) has noted, we are in a moment where sovereignty, sovereign power - and therefore national territoriality - exists as yet another tool in the toolbox, where it is manipulated at will in order to suit particular ends. This form of graduated sovereignty does not work primarily through enclosures; it presumes open systems which must be modulated between. What moves to the fore here is not enclosure or life, but a mechanism or network of mechanisms, including, in this instance, the manipulation of sovereignty in ways that seemingly weaken the state itself. This is a natural byproduct of a society that takes a global political/economic space as its presumption and abandons the concern for life, even as life's utterance, its discursive presence, proliferates.

In sum, biopower is predicated upon a system of enclosures that presume impermeable borders even if they do not exist in practice. The biopolitical organization of social life and political organization centers on and resonates with these enclosures. However, after the generalized crisis of enclosures in the latter half of the 2oth Century into the present, there has arisen a new paradigm of power centered upon open systems. Control, as we will see, organizes social life and political organization away from borders, presumes a dissolution of enclosures, and reterritorializes governance around control mechanisms that are modular, adaptable, highly selective, and not territorial in any traditional sense. 


\section{Deleuze and Control}

Deleuze's concept of control (1995) is about open systems operating in smooth space, rather than enclosures, which he argued were (are) in crisis:

We are in a generalized crisis in relation to all the environments of enclosure - prison, hospital, factory, school, family. The family is an "interior," in crisis like all other interiors - scholarly, professional, etc. ...

\section{He continues:}

Enclosures are moulds, distinct castings, but controls are a modulation, like a selfdeforming cast that will continuously change from one moment to the other, or like a sieve whose mesh will transmute from point to point.

It is not that control is entirely non- or a-territorial, it is that it is an oscillating process between deterritorialization and reterritorialization and requires a mechanism to modulate between them. [16] While Foucault illustrated his modes of power through various technologies, apparatuses, and diagrams, these were largely diagrammatic examples rather than actual functioning mechanisms. Control, however, does not have a paradigmatic example as much as it has a multiplicity of mechanisms:

The conception of a control mechanism, giving the position of any element within an open environment at any given instant (whether animal in a reserve or human in a corporation, as with an electronic collar), is not necessarily one of science fiction. Fe-

lix Guattari has imagined a city where one would be able to leave one's apartment, one's street, one's neighborhood, thanks to one's (dividual) electronic card that raises a given barrier; but the card could just as easily be rejected on a given day or between certain hours; what counts is not the barrier but the computer that tracks each person's position - licit or illicit - and effects a universal modulation. (Deleuze)

Walters (2006) applies Deleuze's diagram of the control society to borders by focusing on three transformations: the spatiality of power or the shift from enclosure to open systems; the shift in the dominant mechanisms and images of power or the shift from the ideal, ordered city to information
[16] A helpful term to think through control's territoriality, only very recently made known to me, is "non-linear territoriality" (Popescu 2011). 
technology and communication; and the subject of power or the shift from the individual/mass body to "dividuals" (191). Within open systems, privileging communication, and working on dividuals who are "partial, fragmented and incomplete" persons, control

de-emphasizes or even abandons the quest to train, moralize, reform and remake the individual. It relinquishes the dream of an all-encompassing, normalized society. It is less bothered with reforming the young offender, than with securing the home or the shopping mall against their presence. (192)

In short, control abandons the ideal subject, and only attempts to minimize the most obvious outliers (i.e. terrorists). Control is indifferent to life: life, territory, sovereignty, and discipline are simply utilized strategically under a process without a subject, a process without goals. Security for whom, or for what? Security today is achieved only by negating meaningful life. Movement curtailed, why, and to what end? Movement is fundamentally liberal, and in the triumph of liberal democracy and liberal economics, why do we insist on rigidly controlling it? Control, ultimately, becomes hegemonic without benefitting anyone; to paraphrase Arendt, how do we contend with the banality of control?[17]

This abandonment brings into clarity the distinguishing feature of control, as opposed to the border enforcement or population management paradigms. Deportation is thus not about shaping the 'correct' populace, as much as it is about producing striations in space otherwise tending toward smoothness. License checkpoints and visa systems determine appropriateness to travel, but do not oppose 'us' versus 'them' (or the dialectic of inclusion versus exclusion). Indeed, by acting as turbulence that redirects a flow, rather than a barrier that excludes, the internalization or externalization of transmigrant policing has fundamentally altered the relation among people, politics, and place. The spatiality of control does not revolve around the resonant centers of state, nation, borders, yet it is not an unmediated deterritorialization. Control reterritorializes along new striations, new power configurations, and new social subjectivities. Precisely by abandoning the ideal subject, control, and its other - precarity - differentiates itself from disciplinary and biopolitical regimes, which work to secure their objects, not radically precarize them. To clarify, sovereign power secures the body of the king, disciplinary power secures the body within enclosure institutions, biopower secures the life of the population; control, however, secures movement, relationships, and assemblages.
[17] This takes us into territory that Deleuze did not begin to cover in his (very short) essay. Nor did he provide in the essay on control societies a sufficient paradigmatic example. I argue that, in terms of population modulation, Bigo (2005) possibly provides that example in the "banopticon." The banopticon uses databases, psychological profiles, biometric data and so on to select out those for scrutiny from the rest; in other words, it fulfills the will to survey the entire populace, but modulates between those deemed 'acceptable' and 'unacceptable': The banopticon form of governmentality is different from Bentham's Panopticon, reread by Foucault. The latter supposes that everyone in a given society is equally submitted to surveillance and control, that there exists a physical proximity between watchers and the watched, as well as an awareness of being under scrutiny... The banopticon, on the contrary, deals with the notion of exception, and the difference between surveillance for all but control of only a few. (6) Leaving aside Bigo's nuanced elaboration of this statement, my point is simple: surveillance for all but control of only a few. To return for a moment to Deleuze's characterization of the electronic card that one day releases you from your neighborhood while the next day leaving you confined at home, the banopticon highlights the mechanism of modulation and the importance of maintaining access to the proper "codes" that keep you in the mobile population. 


\title{
Transmigration and Precarity
}

By the turn of the millennium, economic and social processes that had begun at least in the 1970 s had become fully entrenched, and resulted in a vigorous debate over the meaning of precarity:

\begin{abstract}
At base was an attempt to identify or imagine precarious, contingent or flexible workers as a new kind of political subject, replete with their own forms of collective organization and modes of expression...In its most ambitious formulation it would encompass not only the condition of precarious workers but a more general existential state, understood at once as a source of 'political subjection, of economic exploitation and of opportunities to be grasped' ... Not only the disappearance of stable jobs but also the questions of housing, debt, welfare provision and the availability of time for building affective personal relations would become aspects of precarity... (Neilson/Rossiter 2008, 52)
\end{abstract}

While the term itself has faded from the forefront of labor and social activism, it remains a strong theoretical concept, in part because it works on a number of registers. First, it relates contemporary conditions of employment for many (if not most) workers to those conditions experienced under the welfare state. This relation is clearly a devolution from a tendency toward steady employment at livable wages towards inconsistent, flexible employment at low wages. Second, it points to a combination of conditions that result from a lack of steady employment at livable wages, such as access for the young and/or poor to the housing market or the ability to consume a healthy diet. Most importantly, for my argument here at least, it points to a political question of membership and presence.

The governance of transmigration attempts to control and modulate the effects of migration on the state and capital. It is an attempt to define parameters for and predict the outcomes of forces that are fluid and directionless. Paraphrasing Bigo (2002), transmigration is the perfect mechanism for the governmentality of precarity because migration is such an easy target for crisis narratives. The state can assert the threat to sovereignty by pointing to the relatively small number of criminals or terrorists who clandestinely cross borders and amplify those instances to a generalized fear. It then can advance all sorts of security agendas that would otherwise be unthinkable.[18] Neoliberal capital can follow a parallel path and consolidate new markets based on generalized unease. But they also benefit directly from the precarization of transmigration by getting in return a thoroughly 
docile, largely non-unionized workforce who can be abjectly exploited. However, these nation-state based securitizations, and their "international" counterparts - Frontex, the UN, NATO, etc. - are anachronisms, rapidly bending to the gravitational pull of transplanetary, transmigratory control mechanisms.

There are a few strands running through this essay that I will draw together here. First is the discussion of technologies mobilized to modulate transmigration that tend toward one of three broad strategies: externalization, internalization, and excision. I have begun to show how these strategies are different from previous technologies of power and how and why they apply to control and precarity. Second, there is the assertion that transmigration is becoming a key attractor, or gravitational center, around which the political, economic, and social spheres are gravitating. It is arguable that under sovereign power, discipline, and biopower, transmigration was a state-effect and a capital-effect;[19] now, however, transmigration has taken on a kind of autonomy that is an existential threat to state and capital, hence the overwhelming desire to govern it. Finally, there is the linkage between transmigration and precarity that implies a mutual dependency and a possibility for emergent forms of subjectivity.

Externalization, internalization, and excision are broad strategies which encompass a range of technologies of migration control that focus on modulating flows in novel ways. The EU, US, Australia, and other "migrant receiving states" are actively invested in all of these strategies, pioneering new strategies and sharing them frequently via governmental communication, international conferences, and organizations such as the IOM. What is at stake here is the way these strategies are converging in a global political space that no longer is defined by the inclusion/exclusion dialectic. It is clear that borders have always served an externalization and internalization function - they define the interior and exterior after all; however, what is new is the modulation by which borders achieve this today, which is more akin to a computer's virus protection software than a prophylactic. These strategies help define exceptional categories of political membership, those who experience an "inclusive exclusion" by having a territorial presence without the right to formal legal protections, and those who experience the "exclusive inclusion" by being kept in remote detention centers (i.e. Lampedusa) or on islands declared non-sovereign for the sake of asylum (i.e Australia). In sum, it is not the interior/exterior distinction that matters anymore; what matters is the mechanism that modulates the relationship.
[18] In this sense, the state operates its own shock doctrine (Klein 2007).

[19] A final clarification: I recognize that there exists a great deal of literature aimed toward understanding state-effects as the interlocking relations of individuals, institutions, and policies that produce the effect of "the state." However, by state-effect I mean here quite literally a phenomenon that is only an effect of an entity called "the state" - further clarification saved for another venue. 
Transnational migration has, to an extent, broken from its historical status as state- and capitaleffect. State and capital no longer determine transmigration as much as they act as two attractors among an array of others that influence transmigration flows. Borders have diminished in importance, but not disappeared, and flows of migrants frequently move to places that baffle traditional economic analyses. Indeed, I suspect that the hierarchical relationship of state-capital-migrant has reversed: migrant-capital-state. What forms of political membership can be imagined if we take transmigration as the foundation of political theory? What if we begin with the migrant, or further, the refugee, rather than the citizen? A strong case can be made that transmigration is now the gravitational center around which the political, the economic, and the social orbit.

\section{Bibliography}

Adepoju, A./van Noorloos, F./Zoomers, A. (2009) Europe's Migration Agreements with MigrantSending Countries in the Global South: A Critical Review. In: International Migration 48(3): 42-75.

Agamben, G. (1998) Homo Sacer: Sovereign Power and Bare Life. Stanford, CA: Stanford University Press.

Anderson, B. (2010) Migration, Immigration Controls and the Fashioning of Precarious Workers. In: Work Employment Society 24(2): 300-317.

Andrijasevic, R. (2009) Deported: The Right to Asylum at EU's External Border of Italy and Libya. In: International Migration 48(1): 148-174.

Arendt, H. (1977) Eichmann in Jerusalem: A Report on the Banality of Evil. New York: Penguin.

Bakker, M. (2010) "From 'The Whole Enchilada' to Financialization: Shifting Discourses of Migration Management in North America.” In: Geiger, M./Pécoud, A. (eds.) The Politics of International Migration Management. New York: Palgrave Macmillan.

Bauman, Z. (2004) Wasted Lives: Modernity and Its Outcasts. Malden, MA: Polity Press.

Bauman, Z. (1998) Globalization: The Human Consequences. New York: Columbia University 
Press.

Bigo, D. (2001) The Mobius Ribbon of Internal and External Securities. In: Albert, M./Jacobson, D./Lapid, Y. (eds.) Identities, Borders, Orders. Minneapolis: University of Minnesota Press.

Bigo, D. (2002) Security and Immigration: Toward a Critique of the Governmentality of Unease. In: Alternatives 27(Special Issue), 2002: 63-92.

Bigo, D. (2007) Detention of Foreigners, States of Exception, and the Social Practices of Control of the Banopticon. In: Rajaram, P.K./Grundy-Warr, C. (eds.) Borderscapes: Hidden Geographies and Politics at Territory's Edge. Minneapolis: University of Minnesota Press.

Bigo, D./Guild, E. (2005) "Policing at a Distance: Schengen Visa Policies.” In: Bigo, D./Guild, E. (eds.) Controlling Frontiers: Free Movement Into and Within Europe. Burlington, VT: Ashgate.

Bonelli, L. (2005) "The Control of the Enemy Within? Police Intelligence in the French Suburbs (banlieues) and its Relevance for Globalization.” In: Bigo, D./Guild, E. (eds.) Controlling Frontiers: Free Movement Into and Within Europe. Burlington, VT: Ashgate.

Brown, W. (2010) Walled States, Waning Sovereignty. New York: Zone Books.

Campbell, T. C. (2011) Improper Life: Technology and Biopolitics from Heidegger to Agamben. Minneapolis: University of Minnesota Press.

Clough, P. T./Willse, C. (2011) Beyond Biopolitics: Essays on the Governance of Life and Death. Durham, NC: Duke University Press.

Coleman, M. (2007) Immigration Geopolitics Beyond the Mexico-US Border. In: Antipode 27(1): 54-76.

Coleman, M./Kocher, A. (2011) Detention, Deportation, Devolution and Immigrant Incapacitation in the US, Post-9/11. In: RGS Geographical Journal 177(3): 228-237.

Collyer, M. (2007) In-Between Places: Trans-Saharan Transit Migrants in Morocco and the Fragmented Journey to Europe. In: Antipode 39(4): 668-690.

Collyer, M. (2010) Stranded Migrants and the Fragmented Journey. In: Journal of Refugee Studies 23(3): 273-293.

Crowley, J. (2005). "Where Does the State Actually Start? The Contemporary Governance of Work and Migration.” In: Bigo, D./Guild, E. (eds.) Controlling Frontiers: Free Movement Into and Within Europe. Burlington, VT: Ashgate.

Deleuze, G. (1995) “Postscript on the Societies of Control.” http://www.n5m.org/n5m2/media/ 
texts/deleuze.htm (11/11/11)

Elden, S. (2011) “Territory without Borders." In: Harvard International Review, web feature, http://hir.harvard.edu/territory-without-borders (11/03/12)

Esposito, R. (2008) Bios: Biopolitics and Philosophy. Minneapolis: University of Minnesota Press.

Foucault, M. (1990) History of Sexuality, volume 1: An Introduction. Translated by Robert Hurley. New York: Vintage Books.

Foucault, M. (2003) “Society Must Be Defended:" Lectures at the College de France, 1975-1976. Tranlated by David Macey. New York: Picador.

Foucault, M. (2007) Security, Territory, Population: Lectures at the College de France, 19771978. Translated by Graham Burchell. New York: Picador.

Foucault, M. (2008) The Birth of Biopolitics: Lectures at the College de France, 1978-1979. Translated by Graham Burchell. New York: Picador.

Geiger, M. (2010) “Mobility, Development, Protection, EU-Integration! The IOM’s National Migration Strategy for Albania.” In: Geiger, M./Pécoud, A. (eds.) The Politics of International Migration Management. New York: Palgrave Macmillan.

Geiger, M./Pécoud, A. (2010) The Politics of International Migration Management. New York: Palgrave Macmillan.

Glick Schiller, N./Basch, L./Blanc-Szanton, C. (1992) Towards a Transnational Perspective on Migration: Race, Class, Ethnicity, and Nationalism Reconsidered. New York: New York Academy of Sciences.

Groenendijk, K. (2003) "New Borders Behind Old Ones: Post-Schengen Controls Behind the Internal Borders and Inside the Netherlands and Germany.” In: Groenendijk, K./Guild, E./Minderhoud, P. (eds.) In Search of Europe's Borders. The Hague: Kluwer Law International.

Guild, E. (2003) "The Border Abroad: Visas and Border Controls.” In: Groenendijk, K./Guild, E./ Minderhoud, P. (eds.) In Search of Europe's Borders. The Hague: Kluwer Law International.

Hamood, S. (2008) EU-Libya Cooperation on Migration: A Raw Deal for Refugees and Migrants? In: Journal of Refugee Studies 21(1): 19-42.

Heyman, J. (2007) Entrapment Processes and Immigrant Communities in a Time of Heightened Border Vigilance. In: Human Organization 66(4): 354-360.

Inder, C. (2010) “International Refugee Law, 'Hyper-Legalism’ and Migration Management: The 
Pacific Solution.” In: Geiger, M./Pécoud, A. (eds.) The Politics of International Migration Management. New York: Palgrave Macmillan.

Kasparek, B. (2010) "Borders and Populations in Flux: Frontex's Place in the European Union's Migration Management.” In: Geiger, M./Pécoud, A. (eds.) The Politics of International Migration Management. New York: Palgrave Macmillan.

Klein, N. (2007) The Shock Doctrine: The Rise of Disaster Capitalism. New York: Picador.

Lahav, G. (1998) Immigration and the State: The Devolution and Privatisation of Immigration Control in the EU. In: Journal of Ethnic and Migration Studies 24(4): 675-694.

Lemke, T. (2011) Biopolitics: An Advanced Introduction. New York: New York University Press. Luedtke, A. (2009) "Fortifying Fortress Europe? The Effect of September 11 on EU Immigration Policy.” In: Givens, T. E./Freeman, G. P./Leal, D. L. (eds.) Immigration Policy and Security: U.S., European, and Commonwealth Perspectives. New York: Routledge.

Marchetti, C. (2010) "Expanded Borders: Policies and Practices of Preventive Refoulement in Italy.” In: Geiger, M./Pécoud, A. (eds.) The Politics of International Migration Management. New York: Palgrave Macmillan.

Mitsilegas, V. (2009) "Borders, Security, and Transatlantic Cooperation in the Twenty-First Century: Identity and Privacy in an Era of Globalized Surveillance.” In: Givens, T. E./Freeman, G. P./ Leal, D. L. (eds.) Immigration Policy and Security: U.S., European, and Commonwealth Perspectives. New York: Routledge.

Mountz, A. (2010) Seeking Asylum: Human Smuggling and Bureaucracy at the Border. Minneapolis: University of Minnesota Press.

Nealon, J. (2008) Foucault Beyond Foucault: Power and Its Intensifications Since 1984. Stanford, CA: Stanford University Press.

Negri, A. (1989) Marx Beyond Marx: Lessons on the Grundrisse. New York: Autonomedia.

Neilson, B./Rossiter, N. (2008) Precarity as a Political Concept, or, Fordism as Exception. In: Theory, Culture \& Society 25(7-8): 51-72.

Nunez, G. G./Heyman, J. M. (2007) Entrapment Processes and Immigrant Communities in a Time of Heightened Border Vigilance. In: Human Organization 66(4): 354-365.

Ong, A. (2006) Neoliberalism as Exception: Mutations in Citizenship and Sovereignty. Durham, NC: Duke University Press. 
Popescu, G. (2012) Bordering and Ordering in the Twenty-First Century: Understanding Borders. Lanham, MD: Rowman \& Littlefield.

Protevi, J. Foucault Social Power Chart. http://www.protevi.com/john/Foucault/powerchart.pdf (9 April 2011).

Putignant, P./Streiff-Fénart, J. (2010) "Migration Policy Development in Mauritania: Process, Issues and Actors.” In: Geiger, M./Pécoud, A. (eds.) The Politics of International Migration Management. New York: Palgrave Macmillan.

Rose, N. (2007) The Politics of Life Itself: Biomedicine, Power, and Subjectivity in the TwentyFirst Century. Princeton, NJ: Princeton University Press.

Schinkel, W. (2010) From Zoepolitics to Biopolitics: Citizenship and the Construction of 'Society.' In: European Journal of Social Theory 13(2): 155-172.

Scott, J.C. (1998) Seeing Like a State: How Certain Schemes to Improve the Human Condition Have Failed. New Haven: Yale University Press.

Thielemann, E. R. (2009) "Towards a Common European Asylum Policy: Forced Migration, Collective Security, and Burden Sharing.” In: Givens, T. E./Freeman, G. P./Leal, D. L. (eds.) Immigration Policy and Security: U.S., European, and Commonwealth Perspectives. New York: Routledge.

Varsanyi, M. (2008) Immigration Policing Through the Backdoor: City Ordinances, The 'Right to the City,' and the Exclusion of Undocumented Day Laborers. In: Urban Geography 29(1): 29-52.

Vaughan-Williams, N. (2010) The UK Border Security Continuum: Virtual Biopolitics and the Simulation of the Sovereign ban. In: Environment and Planning D: Society and Space 28(6): $1071-1083$.

Walters, W. (2006) Border/Control. In: European Journal of Social Theory 9(2): 187-203.

Walters, W. (2004) Secure Borders, Safe Haven, Domopolitics. In: Citizenship Studies 8(3): 237260.

Zolberg, A. (2003) The Archaeology of 'Remote Control.' In: Fahrmeir, A./Faron, O./Weil, P. (eds.) Migration Control in the North Atlantic World: The Evolution of State Practices in Europe and the United States from the French Revolution to the Inter-War Period. New York: Berghahn Books. 